\title{
Predictive Value of Serum Sodium Level in Determining Complicated Appendicitis Risk in Children
}

\author{
Gülser Esen Besli ${ }^{1}$, (1) Merve Çetin ${ }^{2}$, C Çiğdem Ulukaya Durakbaşa ${ }^{3}$, \̧eyma Özkanlı4 \\ ${ }^{1}$ Department of Pediatric Emergency, Istanbul Medeniyet University Goztepe Training and Research Hospital, Istanbul, Turkey \\ ${ }^{2}$ Department of Pediatrics, Istanbul Medeniyet University Goztepe Training and Research Hospital, Istanbul, Turkey \\ ${ }^{3}$ Department of Pediatric Surgery, Istanbul Medeniyet University Faculty of Medicine, Goztepe Training and Research Hospital, Istanbul, Turkey \\ ${ }^{4}$ Department of Patology, Istanbul Medeniyet University Faculty of Medicine, Goztepe Training and Research Hospital, Istanbul, Turkey
}

\begin{abstract}
Introduction: Acute appendicitis is one of the most common surgical emergencies in childhood. Early recognition and treatment of children with complicated appendicitis, especially perforated and gangrenous, is very crucial. The aim of the present study was to determine the predictive value of simple blood tests, such as serum sodium ( $\mathrm{Na}$ ) level, C-reactive protein (CRP) level, and blood leukocyte and neutrophil counts, in complicated appendicitis.

Methods: A total of 403 patients who underwent operation with the initial diagnosis of acute appendicitis that was confirmed by surgery and histopathology were evaluated retrospectively. Patients with perforated or gangrenous appendix, generalized peritonitis, and intra-abdominal abscess were identified as complicated appendicitis. Basal serum Na and CRP levels and blood leukocyte and neutrophil counts of patients with complicated and non-complicated appendicitis were compared.

Results: Of the 403 patients, 158 (39.2\%) had non-complicated, and 245 (60.8\%) had complicated appendicitis. No difference was found between the two groups with regard to hyponatremia, leukocytosis, and neutrophilia ( $p>0.05$ ). The risk of complicated appendicitis increased 2.5-fold in patients with elevated CRP (odds ratio: 2.498; 95\% confidence interval: 1.558-4.004). Patients with complicated appendicitis had lower baseline serum Na levels $(p=0.004 ; p<0.05)$. For diagnosis of complicated appendicitis, the cut-off value for Na was $\leq 138 \mathrm{mEq} / \mathrm{L}$ (sensitivity $82.5 \%$ and specificity $31.1 \%$ ).

Discussion and Conclusion: It was concluded that blood leukocyte and neutrophil counts in patients with suspected acute appendicitis in the emergency department were not helpful in determining the risk of complicated appendicitis. Although a basal serum Na level $\leq 138 \mathrm{mEq} / \mathrm{L}$ has a high sensitivity in predicting complicated appendicitis, its specificity is low.

Keywords: Children; complicated appendicitis; c-reactive protein; hyponatremia; leukocyte; neutrophil.
\end{abstract}

$A^{\prime}$ ppendicitis is the most common non-traumatic surgical emergency in childhood. The risk of perforation in childhood is higher than that in adults and is reported to be between $20 \%$ and $74 \%{ }^{[1-3]}$. The clinical course can progress from simple (non-perforated) acute appendicitis to complicated conditions, such as perforation and intraabdominal abscess. Perforated appendicitis is associated with an increase in the number of diagnostic tests and invasive procedures and prolonged hospital stay. Ponsky et al. ${ }^{[2]}$ reported that complications, such as intra-abdominal abscess, wound infection, and postoperative ileus, are reported to occur in $8 \%$ of patients with simple appendicitis and in $39 \%$ of those with perforated appendicitis. In patients with complicated appendicitis, the aim should be to

Correspondence (İletişim): Gülser Esen Besli, M.D. Istanbul Medeniyet Universitesi Goztepe Egitim ve Arastirma Hastanesi,

Cocuk Acil Unitesi, Istanbul, Turkey

Phone (Telefon): +90 5337139727 E-mail (E-posta): besliesen@gmail.com

Submitted Date (Başvuru Tarihi): 26.01.2019 Accepted Date (Kabul Tarihi): 05.02.2019

Copyright 2019 Haydarpaşa Numune Medical Journal

This is an open access article under the CC BY-NC license (http://creativecommons.org/licenses/by-nc/4.0/). 
plan the optimal treatment for minimizing the morbidity, length of hospital stay, and risk of readmission to the hospital due to a complication ${ }^{[4]}$.

In recent years, studies on the antibiotic treatment of pediatric patients with simple appendicitis without surgery have been published. However, the results of this medical therapy, which is an alternative to surgery, are still controversial ${ }^{[5]}$. The early appendectomy and antibiotic treatment protocol have been shown to be associated with lower hospital stay, cost, recurrent abscess, small bowel obstruction, and frequency of hospital readmission after discharge in patients with perforated appendicitis than those in patients undergoing delayed appendectomy after antibiotic treatment ${ }^{[1,6-8]}$. Therefore, early and accurate detection of perforated appendicitis in patients monitored with an initial diagnosis of acute appendicitis in the emergency room is important in determining the appropriate antibiotic therapy and timing of surgery. Ultrasound is the most commonly used imaging method for diagnosis of acute appendicitis. However, in the differentiation of simple and perforated appendicitis, it is reported that the specificity of ultrasound is high, but its sensitivity is low ${ }^{[9,10]}$. There are several studies on the diagnostic value of laboratory tests performed to differentiate perforated appendicitis from simple appendicitis. Leukocyte count, neutrophil count, serum C-reactive protein (CRP) level, and sedimentation rate are among the most investigated parameters in these studies ${ }^{[3,4,11-14]}$. In the literature, data on the relationship between perforated appendicitis and hyponatremia are very limited in pediatric patients.

The aim of the present study was to determine the predictive value of simple blood tests, such as serum sodium $(\mathrm{Na})$ and CRP levels and blood leukocyte and neutrophil counts, in differentiating complicated appendicitis from simple appendicitis in cases with suspected acute appendicitis in the emergency room setting. It was hypothesized that the detection of hyponatremia at the time of emergency room admission was the predictor of complicated appendicitis in children.

\section{Materials and Methods}

\section{Study Group}

The study was conducted retrospectively on patients who were monitored between January 1, 2016 and August 1, 2018 in the pediatric emergency department of a tertiary care hospital in Istanbul and who were operated by pediatric surgery at the same hospital. A total of 403 patients with surgical and histopathological diagnoses of appendicitis were included in the study. The study was approved by the Ethics Committee of the hospital (date: January 2, 2019; registration no.: 2018/0510).

\section{Study Protocol and Definitions}

Data on age, gender, length of hospital stay, basal serum $\mathrm{Na}$ and CRP levels, complete blood counts including leukocyte and neutrophil values, and ultrasound examination results of the patients were recorded. Patients were divided into two groups as non-complicated appendicitis and complicated appendicitis. Patients with perforated or gangrenous appendix, fecal peritonitis, and intra-abdominal abscess according to surgical and histopathological findings were defined as complicated appendicitis $[4,8]$. Demographic characteristics and duration of hospitalization were compared between the two groups. Differences with regard to hyponatremia ( $\mathrm{Na}<135 \mathrm{mEq} / \mathrm{L}$ ), leukocytosis (white blood cells $>10.000 / \mathrm{mm}^{3}$ ), neutrophilia (neutrophils $\left.>7500 / \mathrm{mm}^{3}\right)$, and serum CRP elevation $(>0.5 \mathrm{mg} / \mathrm{dL}$ ) were investigated. Serum $\mathrm{Na}$ and CRP levels and blood leukocyte and neutrophil counts were also quantitatively compared between the groups. The cut-off value, sensitivity, and specificity percentages of the parameters with a significant difference were determined for predicting complicated appendicitis.

\section{Statistical Analyses}

IBM SPSS Statistics 22 (IBM SPSS, Turkey) software was used for statistical analysis. Shapiro-Wilk test was used to analyze conformity to normal distribution of parameters. Descriptive statistics was expressed as mean, standard deviation, median, and frequency for evaluation of data. In comparison of quantitative data, Student's t-test was used for comparison of parameters with normal distribution between the two groups. Mann-Whitney $U$ test was used for comparison of parameters with non-normal distribution between the two groups. In comparison of qualitative data, chi-square test and Yates's continuity correction were used, and relative risk was also calculated. The optimal cut-off value was selected based on the receiver operating characteristic $(\mathrm{ROC})$ curve analysis. A $p$ value $<0.05$ was considered statistically significant.

\section{Results}

Of the 403 patients, 273 (67.7\%) were males, and 130 (32.3\%) were females. The average age of the patients was $11.39 \pm 3.58(1-18)$ years. Among them, 158 (39.2\%) had non-complicated appendicitis, whereas 245 (60.8\%) had complicated appendicitis. No difference was found between the two groups with regard to age and gender. The duration of hospitalization was longer in the complicated appendicitis group $(p=0.000 ; p<0.05)$ (Table 1). When a comparison was made with regard to laboratory 
findings, there was no significant difference between the groups with regard to hyponatremia, leukocytosis, and neutrophilia ( $p>0.05)$. The incidence of elevated serum CRP was higher in patients with complicated appendicitis, and the risk of complicated appendicitis increased 2.5 -fold in patients with elevated serum CRP levels $(p=0.000 ; p<0.05$, odds ratio: 2.498 ; $95 \%$ confidence interval $(\mathrm{Cl})$ : $1.558-$
4.004) (Table 2). Patients with complicated appendicitis had a lower average baseline serum $\mathrm{Na}$ level and a higher median CRP level $(p=0.004$ and $p=0.000$, respectively; $p<0.05$ ) (Table 3). ROC curves and cut-off values obtained for serum $\mathrm{Na}$ and CRP levels in the diagnosis of complicated appendicitis are shown in Figure 1.

Table 1. Comparison of the groups with regard to age, length of hospital stay, and gender

\begin{tabular}{|c|c|c|c|c|}
\hline & \multicolumn{2}{|c|}{ Definitive diagnosis } & \multirow{2}{*}{$\begin{array}{c}\text { Total } \\
\text { Mean士SD }\end{array}$} & \multirow[t]{2}{*}{$\mathbf{p}$} \\
\hline & $\begin{array}{l}\text { Non-complicated } \\
\text { appendicitis } \\
\text { Mean } \pm \text { SD }\end{array}$ & $\begin{array}{l}\text { Complicated } \\
\text { appendicitis } \\
\text { Mean } \pm S D\end{array}$ & & \\
\hline Age (years) & $11.32 \pm 3.31$ & $11.43 \pm 3.74$ & $11.39 \pm 3.58$ & ${ }^{1} 0.768$ \\
\hline Length of hospital stay (days), median & $3.13 \pm 1.95(2)$ & $4.59 \pm 3.65(4)$ & $4.02 \pm 3.18(3)$ & ${ }^{2} 0.000 *$ \\
\hline \multicolumn{5}{|l|}{ Gender, n (\%) } \\
\hline Males & $101(63.9)$ & $172(70.2)$ & $273(67.7)$ & ${ }^{3} 0.188$ \\
\hline Females & $57(36.1)$ & $73(29.8)$ & $130(32.3)$ & \\
\hline
\end{tabular}

${ }^{1}$ Student's t-test; ${ }^{2}$ Mann-Whitney $\mathrm{U}$ test; ${ }^{3}$ Chi-square test; ${ }^{*} \mathrm{p}<0.05$.

Table 2. Comparison of the groups with regard to hyponatremia, leukocytosis, neutrophilia, and CRP level

\begin{tabular}{|c|c|c|c|c|c|}
\hline & \multicolumn{2}{|c|}{ Definitive diagnosis } & Total & $\mathbf{p}$ & $\begin{array}{c}\text { OR } \\
(95 \% \mathrm{Cl})\end{array}$ \\
\hline \multicolumn{6}{|c|}{ Hyponatremia } \\
\hline Present & $29(18.4)$ & $62(25.3)$ & $91(22.6)$ & 0.103 & \\
\hline \multicolumn{6}{|l|}{ Leukocytosis } \\
\hline Present & $134(84.8)$ & $211(86.1)$ & $345(85.6)$ & 0.714 & \\
\hline Absent & $24(15.2)$ & $34(13.9)$ & $58(14.4)$ & & \\
\hline \multicolumn{6}{|l|}{ Neutrophilia } \\
\hline Present & $129(81.6)$ & $206(84.1)$ & $335(83.1)$ & 0.524 & \\
\hline
\end{tabular}

OR: odds ratio; $\mathrm{Cl}$ : confidence interval; Chi-square test; ${ }^{*} \mathrm{p}<0.05$.

Table 3. Comparison of the groups with regard to basal serum Na levels, leukocyte and neutrophil counts, and serum CRP levels

\begin{tabular}{|c|c|c|c|c|}
\hline & \multicolumn{2}{|c|}{ Definitive diagnosis } & \multirow{2}{*}{$\begin{array}{c}\text { Total } \\
\text { Mean } \pm \text { SD }\end{array}$} & \multirow[t]{2}{*}{$\mathbf{p}$} \\
\hline & $\begin{array}{l}\text { Non-complicated } \\
\text { appendicitis } \\
\text { Mean } \pm \text { SD }\end{array}$ & $\begin{array}{l}\text { Complicated } \\
\text { appendicitis } \\
\text { Mean } \pm \text { SD }\end{array}$ & & \\
\hline Basal serum $\mathrm{Na}(\mathrm{mEq} / \mathrm{L})$ & $136.96 \pm 2.54$ & $136.11 \pm 3.03$ & $136.44 \pm 2.88$ & ${ }^{1} 0.004^{*}$ \\
\hline Leukocyte count (/mm³) & $15796.2 \pm 5029.9$ & $16048.6 \pm 5335.2$ & $15949.6 \pm 5212.7$ & ${ }^{1} 0.636$ \\
\hline Neutrophil count $\left(/ \mathrm{mm}^{3}\right)$ & $12609.5 \pm 4945.8$ & $12877.9 \pm 4985.6$ & $12772.7 \pm 4965.6$ & ${ }^{1} 0.597$ \\
\hline Serum CRP (mg/dL) (median) & $3.1 \pm 4.72(1.1)$ & $6.11 \pm 7.24(3.1)$ & $4.92 \pm 6.53(2.2)$ & ${ }^{2} 0.000^{*}$ \\
\hline
\end{tabular}

\footnotetext{
${ }^{1}$ Student's t-test; ${ }^{2}$ Mann-Whitney $\mathrm{U}$ test.
} 


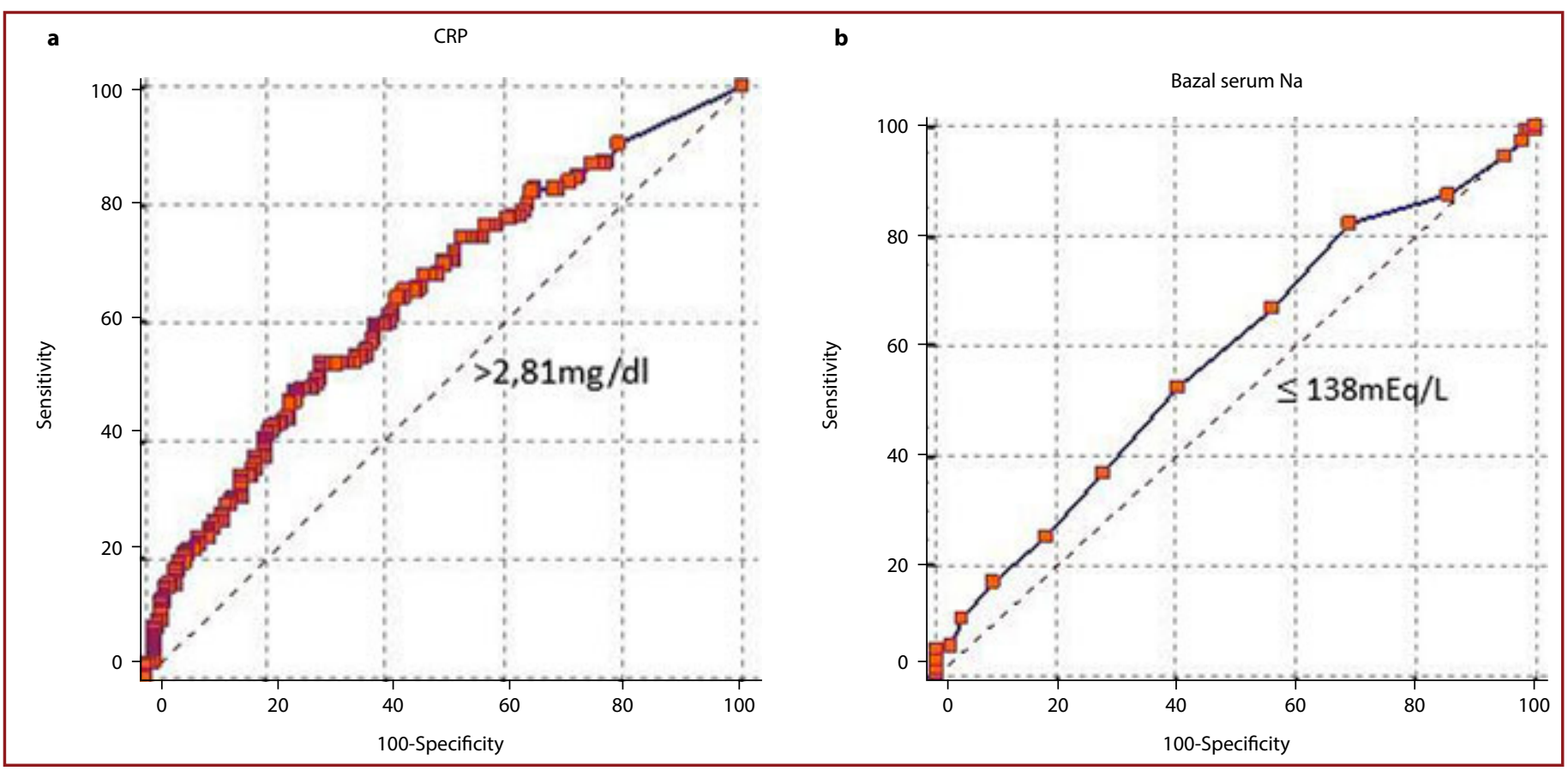

Figure 1. Receiver operating characteristic (ROC) curves obtained for serum CRP and basal serum Na levels in the diagnosis of complicated appendicitis. (a) Area under the curve (AUC): 0.646 (standard error 0.03, $\mathrm{p}=0.001 ; \mathrm{p}<0.05,95 \% \mathrm{Cl}=0.590-0.698$ ). The cut-off value determined for serum CRP is $>2.81 \mathrm{mg} / \mathrm{dL}$. The sensitivity of this value was $53.1 \%$, and specificity was $70.5 \%$. (b) AUC: 0.580 (standard error $0.03, p=0.005 ; p<0.05$, $95 \% \mathrm{Cl}=0.581-0.672$ ). The cut-off value for basal serum Na was $\leq 138 \mathrm{mEq} / \mathrm{L}$. The sensitivity of this value was $82.5 \%$, and specificity was $31.1 \%$.

\section{Discussion}

Early and accurate detection of perforated appendicitis in patients with acute appendicitis in the emergency room is important for determining the appropriate antibiotic therapy and timing of surgery. However, the diagnostic process is rather challenging in children since there is no definitive symptom or finding for clinical prediction of perforated appendicitis, pediatric patients might present with atypical signs and symptoms, and young children are usually unable to express their complaints clearly ${ }^{[12]}$. In the present study, the predictive value of basal serum $\mathrm{Na}$ level and inflammatory markers (leukocyte and neutrophil counts and serum (RP level) in the identification of cases with complicated appendicitis during emergency service monitoring was determined.

There are studies reporting different results and cut-off values on the diagnostic value of inflammatory markers, such as blood leukocyte and neutrophil counts and serum CRP levels in differentiating perforated appendicitis from simple appendicitis in children ${ }^{[3,4,11-14]}$. Williams et al. ${ }^{[3]}$ reported that a leukocyte count $>19.400 / \mathrm{mm}^{3}$ in patients with acute appendicitis is an independent marker for perforated appendicitis, whereas Pham et al. ${ }^{[11]}$ reported this number to be $>12.000 / \mathrm{mm}^{3}$. On the other hand, Lin et al. ${ }^{[15]}$ reported no diagnostic value of leukocytosis and neutrophilia in determining the risk of perforation in pediatric patients with acute appendicitis. However, Nelson et al. ${ }^{[16]}$ reported that there is no difference between the mean leukocyte counts of patients with perforated and non-perforated appendicitis, but patients with perforated appendicitis have higher neutrophil and band counts. Beltran et al. ${ }^{[13]}$ found that leukocyte counts and serum CRP levels are markers with high specificity but low sensitivity when used alone or in combination in differentiating patients with simple and perforated appendicitis. In their study, it was found that the sensitivity of both tests increases when measurements are repeated at intervals during the monitoring in the emergency room. Siddique et al. ${ }^{[17]}$ reported that leukocytosis is a better predictor of serum CRP elevation in the diagnosis of acute appendicitis, and interpretation of leukocytosis and CRP elevation together increase the sensitivity of this test in determining the risk of perforated appendicitis. Another study reported that an elevated CRP level is a marker with high sensitivity and low specificity in differentiating simple and perforated appendicitis ${ }^{[15]}$. In our study, the risk of complicated appendicitis was increased 2.5 -fold in patients with elevated CRP levels. A CRP level $>2.81 \mathrm{mg} / \mathrm{dL}$ was considered as a marker with low sensitivity $(53.1 \%)$ and moderate specificity (70.5\%) in determining complicated appendicitis. There was no difference with regard to 
leukocytosis and neutrophilia in patients with simple and complicated appendicitis.

There are some studies showing that hyponatremia is a predictive marker for perforated/gangrenous appendicitis, ischemic bowel obstruction, and colonic perforation in adult patients ${ }^{[18-21]}$. However, data on the relationship between perforated appendicitis and hyponatremia are very limited in pediatric patients. In a single study evaluating the association between hyponatremia and complicated appendicitis in children, it was found that the risk of complicated appendicitis increased 3-fold in patients with hyponatremia, and that hyponatremia (serum $\mathrm{Na} \leq 135$ $\mathrm{mEq} / \mathrm{L}$ ) was an independent predictor for complicated appendicitis ${ }^{[11]}$. In our study, which hypothesized that the detection of hyponatremia during the initial admission to the emergency room was a predictive finding for complicated appendicitis, no relationship was found between hyponatremia and complicated appendicitis, in contrast with what was expected. However, the mean serum $\mathrm{Na}$ level of patients with complicated appendicitis was found to be significantly lower than that of patients with uncomplicated appendicitis. A basal serum $\mathrm{Na}$ level $\leq 138$ $\mathrm{mEq} / \mathrm{L}$ was found to be a marker in determining the risk of complicated appendicitis; although it had a high sensitivity $(82.5 \%)$, its specificity was found to be low (31.1\%).

The present study has a few limitations. It was performed retrospectively using a single-center data. The basal levels of the laboratory test results obtained only at the time of admission to the emergency room were compared in the study. Since the patients did not have recurrent measurement results obtained at intervals during the preoperative monitoring period, no conclusion could be done about the changes in the results of laboratory tests during the clinical process.

\section{Conclusion}

In conclusion, blood leukocyte and neutrophil counts, which are among the inflammatory markers frequently ordered in patients with suspected acute appendicitis in the emergency room, were not helpful in determining the risk of complicated appendicitis. Although a basal serum $\mathrm{Na}$ level $\leq 138 \mathrm{mEq} / \mathrm{L}$ has a high sensitivity in predicting complicated appendicitis, its specificity is low. Routine testing of basal serum Na levels in patients with suspected acute appendicitis in the emergency room appears to be beneficial in predicting the risk of complicated appendicitis, as well as in fluid and electrolyte management.

Peer-review: Externally peer-reviewed.

Authorship Contributions: Concept: G.E.B., M.Ç., Ç.U.D., Ş.Ö.; De- sign: G.E.B., M.Ç., Ç.U.D., Ş.Ö.; Data Collection or Processing: M.Ç., Ş.Ö.; Analysis or Interpretation: G.E.B., M.Ç.; Literature Search: G.E.B., M.Ç.; Writing: G.E.B.

Conflict of Interest: None declared.

Financial Disclosure: The authors declared that this study received no financial support.

\section{References}

1. Church JT, Klein EJ, Carr BD, Bruch SW. Early appendectomy reduces costs in children with perforated appendicitis. J Surg Res 2017;220:119-24. [CrossRef]

2. Ponsky TA, Huang ZJ, Kittle K, Eichelberger MR, Gilbert JC, Brody $F$, et al. Hospital and patient level characteristics and the risk of appendiceal rupture and negative appendectomy in children. JAMA 2004;292:1977-82. [CrossRef]

3. Williams RF, Blakely ML, Fischer PE, Streck CJ, Dassinger MS, Gupta $\mathrm{H}$, et al. Diagnosing ruptured appendicitis preoperatively in pediatric patients. J Am Coll Surg 2009;208:819-25.

4. Gosain A, Williams RF, Blakely ML. Distinguishing acute from ruptured appendicitis preoperatively in the pediatric patient. Adv Surg 2010;44:73-85. [CrossRef]

5. Xu J, Adams S, Liu YC, Karpelowsky J. Nonoperative management in children with early acute appendicitis: A systematic review. J Pediatr Surg 2017;52:1409-15. [CrossRef]

6. Blakely ML, Williams R, Dassinger MS, Eubanks JW, Fischer P, Huang EY, et al. Early vs interval appendectomy for children with perforated appendicitis. Arch Surg 2011;146:660-5.

7. Myers AL, Williams RF, Giles K, Waters TM, Eubanks JW 3rd, Hixson SD, et al. Hospital cost analysis of a prospective, randomized trial of early vs interval appendectomy for perforated appendicitis in children. J Am Coll Surgeons 2012;214:427-34.

8. Holcomb GW 3rd, St Peter SD. Current management of complicated appendicitis in children. Eur J Pediatr Surg 2012;22:207-12.

9. Blumfield E, Nayak G, Srinivasan R, Muranaka MT, Blitman NM, Blumfield $A$, et al. Ultrasound for differentiation between perforated and non-perforated appendicitis in pediatric patients. AJR Am J Roentgenol 2013;200:957-62. [CrossRef]

10. Carpenter JL, Orth RC, Zhang W, Lopez ME, Mangona KL, Guillerman RP. Diagnostic performance of US for differentiating perforated from non-perforated pediatric appendicitis: $A$ prospective cohort study. Radiology 2017;282:835-41. [CrossRef]

11. Pham X-B D, Sullins VF, Kim DY, Range B, Kaji AH, De Virgilio $\mathrm{CM}$, et al. Factors predictive of complicated appendicitis in children. J Surg Res 2016;206:62-6. [CrossRef]

12. Howell EC, Dubina ED, Lee SL. Perforation risk in pediatric appendicitis: assessment and management. Pediatric Health Med Ther 2018;9:135-45. [CrossRef]

13. Beltran MA, Almonacid J, Vicencio A, Gutie'rrez J, Cruces KS, Cumsille MA. Predictive value of white blood cell count and C-reactive protein in children with appendicitis. J Pediatr Surg 2007;42:1208-14. [CrossRef]

14. Abdella MR, Sayed N. Elevated serum bilirubin as a preoperative specific predictor for complicated appendicitis in chil- 
dren. Egypt J Surg 2015;34:71-8.

15. Lin CJ, Chen JD, Tiu CM, Chou YH, Chiang JH, Lee CH, et al. Can ruptured appendicitis be detected preoperatively in the ED? Am J Emerg Med 2005;23:60-6.

16. Nelson DS, Bateman B, Bolte RG. Appendiceal perforation in children diagnosed in a pediatric emergency department. Pediatr Emerg Care 2000;16:233-7. [CrossRef]

17. Siddique K, Baruah P, Bhandari S, Mirza S, Harinath G. Diagnostic accuracy of white cell count and C-reactive protein for assessing the severity of paediatric appendicitis. JRS Med Short Rep 2011;2:59. [CrossRef]

18. Kim DY, Nassiri N, De Virgilio C, Ferebee MP, Kaji AH, Hamil- ton CE, et al. Association Between Hyponatremia and Complicated Appendicitis. JAMA Surg 2015;150:911-2. [CrossRef]

19. Kaser SA, Furler R, Evequoz DC, Maurer CA. Hyponatremia is a specific marker of perforation in sigmoid diverticulitis or appendicitis in patients older than 50 years. Gastroenterol Res Pract 2013;2013:462891. [CrossRef]

20. Falor AE, Zobel M, Kaji A, Neville A, De Virgilio C. Admission variables predictive of gangrenous cholecystitis. Am Surg 2012;78:1075-8.

21. O'Leary MP, Neville AL, Keeley JA, Kim DY, de Virgilio C, Plurad DS. Predictors of ischemic bowel in patients with small bowel obstruction. Am Surg. 2016;82:992-4. 